\title{
Endocrine disruption induced by organotin compounds; organotins function as a powerful agonist for nuclear receptors rather than an aromatase inhibitor
}

\author{
Tsuyoshi Nakanishi ${ }^{1,2}$ \\ ${ }^{1}$ Laboratory of Hygienics, Gifu Pharmaceutical University, 5-6-1 Mitahora-higashi, Gifu 502-8585, Japan \\ 2Department of Toxicology, Graduate School of Pharmaceutical Sciences, Osaka University, Japan
}

(Received January 28, 2008)

\begin{abstract}
Organotin compounds have been widely used as antifouling biocides for ships and fishing nets, agricultural fungicides and rodent repellents. These widespread uses have resulted in the release of increasing amounts of organotins into the environment. In aquatic invertebrates, particularly marine gastropods, organotin compounds, such as tributyltin (TBT) and triphenyltin (TPT), induce irreversible sexual abnormality in females which is termed "imposex" at very low concentrations. Although it has been theorized that these compounds act as potential competitive inhibitors of aromatase, which converts androgen to estrogen, and then increase levels of unconverted androgens in gastropods, their effective concentrations for aromatase inhibition are high. In addition to wildlife, organotins may have various undesirable effects on human health. Contrary to the theory of organotin-induced aromatase inhibition in gastropods, in human choriocarcinoma cells, these compounds markedly enhance estradiol biosynthe-

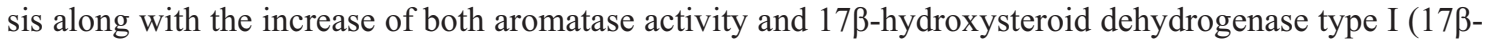
HSD I) activity, which converts low-activity estrogen estrone to the biologically more active form estradiol, at the same low concentrations. Although there are many reports describing the potential toxicity of organotins in human and mammals, the critical target molecules for the toxicity of organotin compounds remain unclear. Recently, organotin compounds including TBT and TPT were identified as nanomolar agonists for retinoid X receptor (RXR) and peroxisome proliferator-activated receptor (PPAR) $\gamma$, which are members of the nuclear receptor superfamily. Here, we review the potential genetics action and subsequent toxicity induced by organotins via these nuclear receptors.
\end{abstract}

Key words: Organotin, Retinoid X receptor (RXR), Peroxisome proliferator-activated receptor (PPAR) $\gamma$, Aromatase, Endocrine disruptor

\section{INTRODUCTION}

Organotin compounds, such as tributyltin (TBT) and triphenyltin (TPT), have been widely utilized as biocides, agricultural fungicides, wood preservatives, and disinfecting agents in circulating industrial cooling waters and in antifouling paints for marine vessels (Boyer, 1989; Fent, 1996). Due to its widespread use as an antifouling agent in boat paints, organotin is a common contaminant of marine and freshwater ecosystems exceeding acute and chronic toxicity levels. Organotins are one of the most significant pesticides in marine and freshwaters and consequently its environmental level, fate and toxicity are of current concern. The toxic potentials of organ- otins to various aquatic organisms are well documented. Especially, many studies dealing with the toxic effects of organotin compounds on sexual development and reproductive function are focused to gastropods. For example, very low concentrations of TBT and TPT induce irreversible sex-organ alterations in females, a phenomenon known as "imposex" (Horiguchi et al., 1997; Matthiessen and Gibbs, 1998). These abnormalities are the result of a masculinization process by which male sex organs develop, notably a penis and a vas deferens. In certain species, growth of a vas deferens disrupts the structure and function of the oviducts, preventing normal breeding activity and causing population decline. Therefore, these organotins have been suspected as endocrine-disrupting chemi-

Correspondence: Tsuyoshi Nakanishi (E-mail: nakanishi@gifu-pu.ac.jp) 
cals to masculinize reproductive organs in not only invertebrates but also vertebrates.

\section{POSSIBLE HUMAN EXPOSURE TO ORGANOTIN COMPOUNDS}

Human exposure to non-point sources of organotins may occur mainly through contaminated dietary sources, such as seafood, shellfish and food crops. Daily intakes of TBT oxide (TBTO) determined in Japan by the duplicated-position method were $4.7 \pm 7.0 \mu \mathrm{g} /$ day in $1991(\mathrm{n}=39)$ and $2.2 \pm 2.2 \mu \mathrm{g} /$ day in $1992(\mathrm{n}=40)$. Using the marketbased method, the daily intake was estimated at 6 9 $\mu \mathrm{g}$ / day in 1991 and 6 7 $\mu \mathrm{g}$ /day in 1992 (Tsuda et al., 1995). In Finland, TPT were detected as the predominant compounds at a level up to $1.11 \mathrm{ng} / \mathrm{g}$ fresh weights in fish and seafoods (Rantakokko et al., 2006). In addition, a variety of mono- and dialkyltins, which include significant contaminating trialkyl species, are also prevalently used as heat stabilizers in the manufacture of polyolefin plastics, bringing them into closer contact with drinking water and food supplies (Takahashi et al., 1999).

The information on human exposure to organotin compounds is limited. In a study of eight volunteers from Germany, TPT was detectable in serum at the concentration ranges $0.17-0.67 \mu \mathrm{g} / 1$ (Lo et al., 2003). In a study of 38 volunteers from the USA, Kannan et al. reported that monobutyltin (MBT), dibutyltin (DBT) and TBT were detected in 53,81 , and $70 \%$ of the 32 blood samples tested. Blood concentrations of MBT, DBT and TBT were $8.17 \pm 8.56,4.94 \pm 3.83$, and $8.18 \pm 15.4 \mathrm{ng} / \mathrm{ml}$, respectively (Kannan et al., 1999). The toxicological significance of the concentrations of organotins measured in these studies is unknown. However, the potential exposure of humans to organotins has aroused great concern about their potential toxicity. Animal experiments suggested that the spectrum of potential adverse chronic systemic effects of organotins in humans is quite broad and includes primary immunosuppressive, endocrinopathic, neurotoxic metabolic, and enzymatic activity, as well as potential ocular, dermal, cardiovascular, upper respiratory, pulmonary, gastrointestinal, blood dyscrasias, reproductive/teratogenic/developmental, liver, kidney, bioaccumulative, and possibly carcinogenic activity. Although many reports have described the potential toxicity of organotins, the critical target molecules for the toxicity of organotin compounds remain unclear.

\section{ORGANOTINS AS ENDOCRINE-DISRUPTING CHEMICALS}

The synthesis of sex steroids from cholesterol requires trafficking between mitochondria and smooth endoplasmic reticulum, and involves many enzymatic steps. Most of these steps use cytochrome P450 (CYP) haem-containing enzymes, and the genes coding for these enzymes are abbreviated to CYP (Fig. 1). Some organotins compounds are known as endocrine-disrupting chemicals to modulate steroid hormone biosynthesis. As mentioned above, these organotins have been suspected to masculinize reproductive organs in vertebrates because, in some gastropods, very low concentrations of these organotins induce "imposex" (Horiguchi et al., 1997; Matthiessen and Gibbs, 1998). Some evidences have theorized that these organotisns act as a specific inhibitor of aromatase enzyme which converts androgen to estrogen (Bettin et al., 1996; Matthiessen and Gibbs, 1998). For example, exposure of the organotins increased testosterone levels in female gastropods and organotin-induced imposex can be mimicked by a specific inhibitor of aromatase (Bettin et al., 1996). In addition, TBT was reported to be catalyzed to dibutyltin, which is a metabolite of TBT, by aromatase enzyme (Lee, 1985). However, it has remained unclear whether organotin compounds especially inhibit catalytic activity of aromatase in vertebrates.

Actually, can organotin compounds inhibit the catalytic activity of aromatase? The answer to the question seems to be 'Yes'. In in vitro experiments, butyltins are demonstrated to exhibit structure-related inhibition of the catalytic activity of human aromatase protein from human placenta (Heidrich et al., 2001) or transfected cells (Cooke, 2002). However, at concentrations effective (micromolar level) for the inhibition of aromatase, TBT and TPT are generally toxic to mammalian cells because

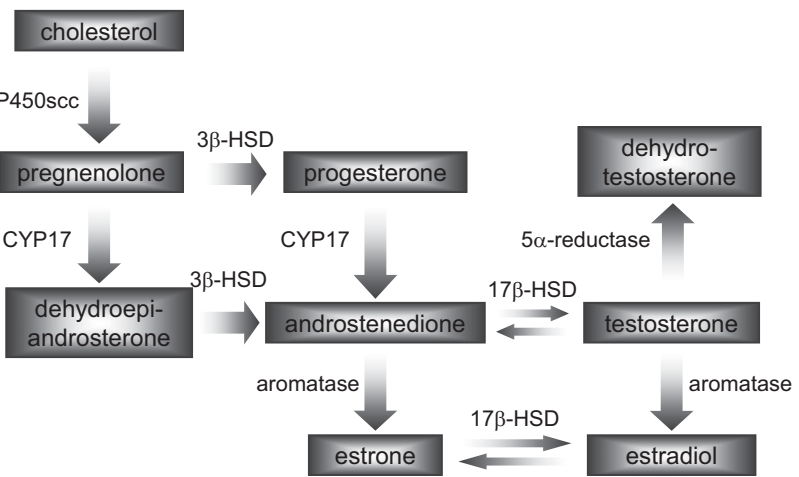

Fig. 1. Pathway of steroid hormone biosynthesis. 
Endocrine disruption of organotins via nuclear receptor signaling

they cause apoptosis or necrosis (Saitoh et al., 2001; Nakanishi et al., 2002; Watanabe et al., 2003; Nakanishi et al., 2006). In human choriocarcinoma cell lines, JAr, JEG-3 and BeWo, exposure to greater than $300 \mathrm{nM}$ TBT or TPT markedly decreases DNA and protein synthesis (Nakanishi et al., 2002; Nakanishi et al., 2006). Concentrations under $1 \mu \mathrm{M}$ of either organotin compound did not significantly affect aromatase activity in microsomes isolated from human choriocarcinoma cells (Nakanishi et al., 2002). In addition to aromatase, at above $1 \mu \mathrm{M}$, TBT inhibit the catalytic activity of human $5 \alpha$-reductase I and II (Doering et al., 2002), rat 3 $\beta$-hydroxysteroid dehydrogenase (3 $\beta$-HSD) (McVey and Cooke, 2003) and pig 17 $\beta$-HSD I (Ohno et al., 2005). At the same concentration ranges, TPT also inhibit the catalytic activity of human aromatase, $5 \alpha$-reductase II $17 \beta$-HSD I and III (Lo et al., 2003). These observations suggest that these organotin compounds at micromolar level inhibit not specific to the catalytic activity of aromatase and we have to consider the toxicity of organotin compounds in distinguishing between nonspecific toxicity to cells and the specific inhibition of steroidogenic enzymes.

In additon to these, sex steroid receptors and steroidogenic enzymes for sex steroid hormones have not yet been identified in gastropods, and it remains unclear whether sex steroid hormones are critical factors for sexual development and reproduction in gastropods. Furthermore, homologues of both the estrogen receptor (ER) and androgen receptor (AR) have not been found in invertebrates (Escriva et al., 2000) and the composition of nuclear receptor family members is very different between vertebrates and invertebrates (Escriva et al., 1997; Escriva et al., 2000). Therefore, there is some doubt as to whether organotin compounds function as inhibitors of enzymes that metabolize androgens in gastropods, and this doubt led us to suspect that organotin compounds affect other target molecules in mammals.

\section{ORGANOTIN COMPOUNDS AFFECT ENDOCRINE FUNCTIONS IN HUMAN PLACENTA AND OVARY}

In a recent study, Nakanishi et al. investigated the effects of organotin compounds on aromatase activity (Nakanishi et al., 2002; Nakanishi et al., 2005) and $17 \beta$-HSD I, which converts low-activity estrone to highactivity estradiol (Nakanishi et al., 2006), in human choriocarcinoma cells. Both TBT and TPT increased the catalytic activity of aromatase and $17 \beta$-HSD I along with their mRNA expression in a dose-dependent fashion following exposure to non-toxic concentration ranges (3-
$100 \mathrm{nM})$. These results indicate that the observed organotin-induced alterations in human choriocarcinoma cells are due to the regulation of mRNA levels of both steroidogenic enzymes, not of the enzyme complex. In addition, these organotin compounds also markedly stimulated human chorionic gonadotropin (hCG) production in the same concentration ranges, along with its mRNA expression (Nakanishi et al., 2002; Nakanishi et al., 2005). These results suggest that organotin compounds are potent stimulators of human placental estrogen biosynthesis and hCG production in vitro and that the placenta represents a potential target organ in pregnant women for organotin compounds, the endocrine-disrupting effects of which might be the result of local changes in estrogen and hCG concentrations.

In opposition to the above results, however, Saitoh et al. reported that $20 \mathrm{ng} / \mathrm{ml}$ (about $60 \mathrm{nM}$ ) TBT and TPT suppressed both the activity and gene expression of aromatase in the human ovarian granulose-like cell line, KGN (Saitoh et al., 2001). This discrepancy in the action of organotins on the gene expression of human aromatase is due to the tissue-specific expression of aromatase, which is strictly regulated (Fig. 2). Human CYP19 is a single-copy gene composed of 10 exons; exons II to $\mathrm{X}$ encode the aromatase protein, as well as the $3^{\prime}$ untranslated region of mRNA common to all estrogen-producing tissues (Simpson et al., 1994). A number of variations of exon I exist. These encode the $5^{\prime}$ untranslated regions of various CYP19 mRNAs, which are selectively expressed in some tissues by alternative splicing (Simpson et al., 1994; Sebastian and Bulun, 2001; Bulun et al., 2003). The tissue-specific expression of CYP19 in humans appears to be mediated by tissue-specific promoters lying upstream of the respective exon I sequences, and by transcription

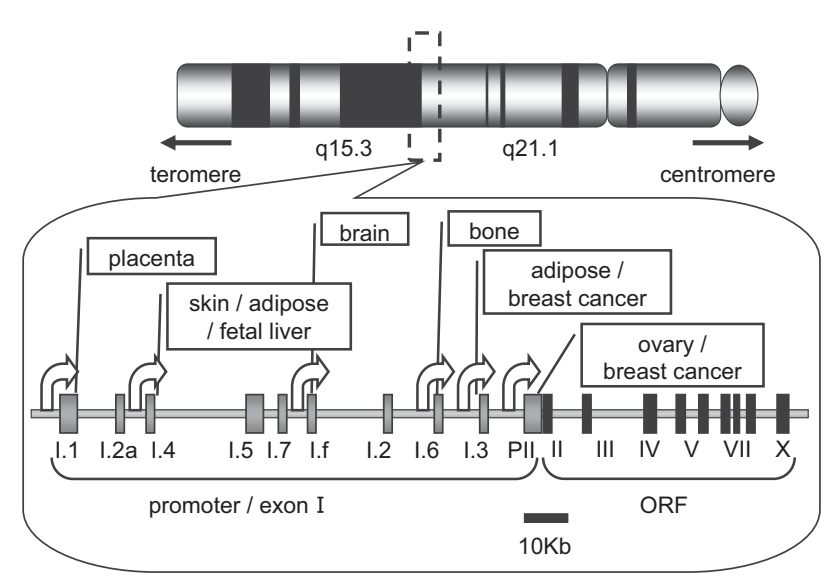

Fig. 2. Genomic organization of human CYP19 gene 
factors binding to specific regions of each promoter. In the placenta, CYP19 is driven by the placental major promoter (I.1), and the transcript contains exon I.1, located approximately $89 \mathrm{~kb}$ upstream from exon II. On the other hand, ovarian transcripts contain a sequence at the 5 '-end immediately upstream of the translation start site, because gene expression in the ovary uses a proximal promoter (II). In ovarian granulosa cells, the expression of CYP19 is strongly regulated by the steroidogenic tissue-specific transcriptional factor, $\mathrm{Ad} 4 \mathrm{Bp} / \mathrm{SF}-1$, via promoter II. In contrast, Ad4Bp/SF-1 is expressed at very low levels in the human placenta and may not play an important role in activation of the placental major promoter I.1 (Bamberger et al., 1996; Simpson et al., 1997). Saitoh et al. suggest that the effects of organotin compounds in KGN cells are caused partly by association with Ad4Bp/SF-1 (Saitoh et $a l ., 2001)$. It is therefore likely that the action of organotin compounds in human placental cells is induced by a pathway clearly different from that in ovarian granulosa cells, giving rise to the promotion of aromatase activity and mRNA expression.

In human placental cells, all mRNA expressions of aromatase, 17 $\beta$-HSD I and hCG are controlled by cAMPdependent intracellular signal pathways; however, neither TBT nor TPT exerted any effect on intracellular cAMP production (Nakanishi et al., 2002). In addition, there is little possibility that these organotin compounds affect the cAMP-protein kinase A (PKA) pathway in the human ovary, because it stimulates aromatase gene expression through promoter II (Michael et al., 1995). The possible target of these organotin compounds may be a signaling pathway common to the gene expression of aromatase, $17 \beta$-HSD I and hCG in the human placenta and ovary.

\section{ORGANOTIN COMPOUNDS ARE PPARY AND RXR AGONISTS}

Nuclear receptors play important roles in maintenance of the endocrine system, regulation of organ differentiation and fetal development. Reproductive abnormalities in wildlife can be associated with exposure to environmental pollutants capable of mimicking the action of natural hormones. As the nuclear receptors of intrinsic hormone systems are likely to be targets of industrial chemicals, information on their ability to bind these chemicals is valuable for environmental risk assessment. Recently, Kanayama et al. reported assay systems for human nuclear receptors to determine whether suspected endocrine disruptors can bind to members of the nuclear receptor family on the basis of the previously described CoA-BAP system (Kanayama et al., 2003). Using these systems, they found that TBT and TPT were potential agonists of retinoid X receptor (RXR) and peroxisome proliferator-activated receptor (PPAR) $\gamma$ (Kanayama et al., 2005). In addition, these compounds also induced the transactivation function of RXR and PPAR $\gamma$ in mammalian culture cells. The effectiveness of each organotin compound was comparable to that of the natural ligand of RXR, 9-cis retinoic acid (9cRA) or the well-known PPAR $\gamma$ ligand rosiglitazone (Rosi) (Kanayama et al., 2005). The dose ranges of TBT and TPT that induced transactivation were from 10 to $100 \mathrm{nM}$, which do not cause significant apoptosis or necrosis of mammalian culture cells in general. These results indicate that these organotin compounds function as RXR or PPAR $\gamma$ agonists in mammalian cells.

RXR stand out as unique members of the type II nuclear receptor subfamily and play dual roles in nuclear receptor signaling. On one hand, they can bind to their own response element ( $\mathrm{RXR}$ response element) as a homodimer and activate transcription in response to their ligands, and on the other hand, they serve as partners for other nuclear receptors (Chambon, 1996; Giguere, 1994; Aranda and Pascual, 2001). The existence of three types of heterodimers-fully permissive, conditionally permissive and nonpermissive-has been described. In the first case, PPARs/RXR, farnesoid X-activated receptor (FXR) /RXR and liver X receptor (LXR) /RXR heterodimers exhibit dual ligand permissivity, because they can be activated by the agonists of either RXR or its partner receptor, or both, in a more-than-additive fashion (Kliewer et al., 1992; Issemann et al., 1993; Bardot et al., 1993; Mukherjee et al., 1997; Westin et al., 1998; Schulman et al., 1998; Laffitte et al., 2000). As an example of the second type, the RXR/ retinoic acid receptor (RAR) heterodimer exhibits conditional permissivity because a full response to RXR agonists occurs only in the presence of an RAR agonist (Westin et al., 1998; Germain et al., 2002). The third type is the nonpermissive heterodimer, such as the RXR/thyroid hormone receptor and RXR/vitamin D receptor, which cannot be activated by RXR agonists regardless of the presence (or absence) of the agonist of its partner receptor; formation of the heterodimer is thought to actually preclude the binding of the ligand to RXR (Forman et al., 1995; Thompson et al., 1998). TBT and TPT simulated the transactivation of an RXR homodimer and PPAR $\gamma / \mathrm{RXR}$ heterodimer at non-toxic concentration ranges (10-100 $\mathrm{nM})$, whereas they had no effect on the transactivation of RXR/TR and RXR/ RAR heterodimers (Nakanishi et al., 2005). Although the effects of organotin compounds on the transactivation of permissive RXR heterodimers other than PPAR $\gamma / R X R$ have not been determined, it is probably possible to stim- 
Endocrine disruption of organotins via nuclear receptor signaling

ulate the transactivation of other heterodimers because these compounds function as RXR agonists.

\section{REGULATION OF AROMATASE GENE EXPRESSION BY ORGANOTIN COMPOUNDS THROUGH RXR OR PPARY ACTIVATION IN HUMANS}

Gene expression of human aromatase is regulated by the activation of PPAR $\gamma$ and/or RXR. In the human placenta, a selective RXR ligand stimulates aromatase gene expression; however, a selective PPAR $\gamma$ ligand has little or no effect on aromatase gene expression (Sun et al., 1998; Nakanishi et al., 2005). In addition, the PPAR ligand 15-deoxy- $\Delta^{12,14}$-prostaglandin $J_{2}(24)$, FXR ligand chenodeoxycholic acid (Nakanishi et al., 2005) and LXR ligand T0901317 (Nakanishi et al. unpublished data), which are agonists of permissive heterodimer partners of RXR, all also failed to increase mRNA expression of aromatase in human choriocarcinoma cells. It is suggested that none of these pemissive heterodimers are involved in aromatase expression in the human placenta and that RXR homodimer may be required for the regulation of aromatase expression (Fig. 3).

Unlike in the placenta, both RXR- and PPAR $\gamma$-selective ligands suppress aromatase gene expression in the ovary (Mu et al., 2000; Mu et al., 2001; Fan et al., 2005). However, it was suggested that PPAR $\gamma /$ RXR may inhibit promoter II lying upstream of the ovarian major exon I (PII) by an indirect mechanism because of the absence of a PPAR $\gamma / \mathrm{RXR}$ response element in promoter II of aromatase (Mu et al., 2001). A transcriptional factor, nuclear factor-kB $(\mathrm{NF}-\kappa \mathrm{B})$, interacts with the ovarian promoter II sequence of aromatase and up-regulates its gene expression in the human ovary. In addition, activation of the PPAR $\gamma / \mathrm{RXR}$ heterodimer interferes with the interaction between NF- $\kappa \mathrm{B}$ and promoter II sequence of aromatase (Fan et al., 2005). PPAR $\gamma / \mathrm{RXR}$, in the ovary, may regulate aromatase gene expression via the NF- $\mathrm{\kappa B}$ signaling pathway (Fig. 3).

In light of these findings, human aromatase expression regulated by organotin compounds may involve the activation of PPAR $\gamma$ and/or RXR (Saitoh et al., 2001; Nakanishi et al., 2002; Nakanishi et al., 2005), because the aromatase expression pattern induced in the human placenta and ovary by activation of PPAR $\gamma$ and/or RXR is similar to that induced by organotin compounds (Fig. 3). It has already been found, as supporting evidence, that organotin compounds stimulate the expression of a luciferase reporter construct containing the human placental promoter I.1 sequence of aromatase via a ligand-depend- ent signaling pathway of RXR (Nakanishi et al., 2005).

\section{POTENTIAL TOXICITY BY ORGANOTIN COMPOUNDS THROUGH RXR OR PPARY ACTIVATION IN MAMMALS}

PPAR $\gamma$ is activated by a variety of fatty acids and a class of synthetic antidiabetic agents, thiazolidinediones (Lehmann et al., 1995). PPAR $\gamma$ agonists such as Rosi are used to treat type II diabetes and reverse insulin resistance in the whole body by sensitizing the muscle and liver tissue to insulin. In addition, PPAR $\gamma$ also serves as an essential regulator of adipocyte differentiation and lipid storage in mature adipocytes (Tontonoz et al., 1994). Unfortunately, the adipogenic activity of PPAR $\gamma$ may result in undesirable effects such as obesity. RXR agonists also activate the PPAR $\gamma /$ RXR heterodimer and act as insulin-sensitizing agonists in rodents (Mukherjee et al., 1997), underscoring the potential effects of both PPAR $\gamma$ and RXR agonists on diabetes and obesity. In light of these previous findings, Kanayama et al. evaluated the effects of TPT and TBT on adipogenesis and found that these organotins stimulate the differentiation of preadipocyte 3T3L1 cells into adipocytes (Kanayama et al., 2005). These results suggested that organotin compounds are a potential obesogen. A recent study from Grün et al. showed that, in vivo, acute exposure to TBT in adult mice resulted

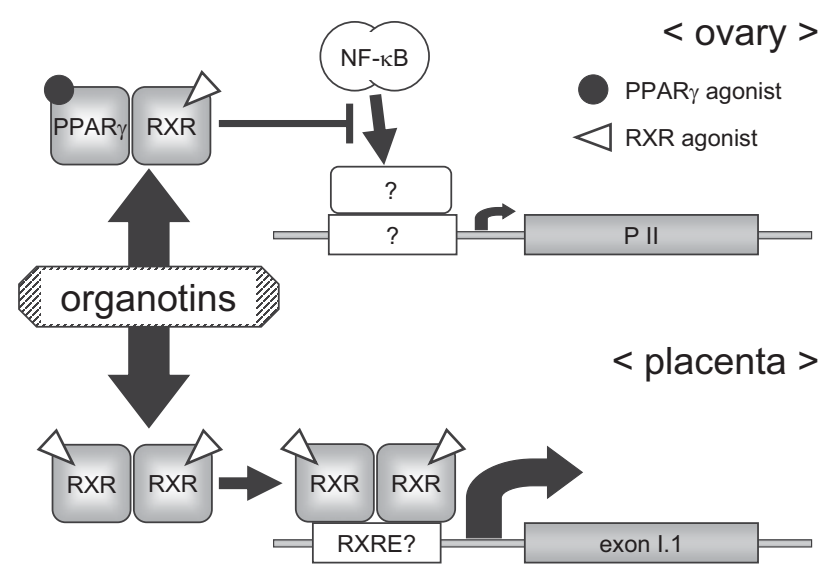

Fig. 3. Human aromatase promoter I.1 and II are regulated by activation of PPAR $\gamma$ and/or RXR. In the ovary, organotins are ligands for PPAR $\gamma$ and RXR and may downregulate aromatase gene expression through suppression of NF-kB-dependent aromatase activation. On the other hand, in the placenta, organotins may induce aromatase gene expression by transactivation of RXR homodimer, without involving PPAR $\gamma$ signaling pathway. 
in coordinate regulation of lipogenic PPAR $\gamma / \mathrm{RXR}$ target gene expression in adipose tissue and liver, and modulated adipocyte differentiation factors such as a members of the CCAAT/enhancer binding protein family and sterol regulatory element-binding protein 1c (Grün et al., 2006). Furthermore, developmental exposure in utero led to a fatty liver (hepatic steatosis) phenotype and enhanced lipid staining of neonatal fat deposits, and resulting in a significant increase in the epididymal fat pad size of mice later in life (Grun et al., 2006). Whether this occurs through increased lipid storage, an increase in adipocyte number, or a combination of both is currently unresolved. However, activation of PPAR $\gamma / \mathrm{RXR}$ induced by organotin compounds represents a compelling mechanistic example of a class of environmental pollutants that have the ability to impact key adipogenic factors, fat deposit size and function.

Exposure of rats in utero to TBT induces a dramatic increase in the incidence of low-birth-weight fetuses because of maternal hypothyroidism (Adeeko et al., 2003). On the other hand, the RXR agonist bexarotene causes clinically significant hypothyroidism in patients with cutaneous T-cell lymphoma (Duvic et al., 2001), and experimental exposure of rats to LG100268 (a selective RXR agonist) induces the acute phase of hypothyroidism (Liu et al., 2002). Similarities between the toxicity of TBT and selective RXR agonists suggest that at least some of the toxic effects of organotin compounds may be mediated by RXR.

Yamabe et al. reported that TBT and TPT enhance the proliferation of androgen-dependent human prostate cancer cells and the transactivation of AR (Yamabe et al., 2000). However, the AR antagonist flutamide cannot inhibit organotin-mediated AR transactivation (Yamabe et al., 2000), and these organotin compounds do not function as AR agonists in a yeast two-hybrid system (Nishikawa et al. unpublished data). Recently, RXR was found to function as a novel co-regulator of AR, and 9cRA was found to inhibit AR activity through the activation of RXR (Chuang et al., 2005). It remains unclear whether the co-regulators recruited by organotin-activated RXR are different from those recruited by 9cRA, but RXR activation by organotins might be involved in the AR transactivation induced by them.

Taken together, these compounds may cause adverse effects on mammals through the activation of PPAR $\gamma$ and/ or RXR because of the above-described toxic effects of organotin compounds in human cells and experimental animals.

\section{CONCLUSIONS}

Although organotin compounds inhibit the enzymatic activity of aromatase, their effective concentration is toxic for mammalian cells. In this review, we have proposed the activation of PPAR $\gamma$ and/or RXR as a novel mechanism for organotin-induced toxic effects in mammals. In addition, RXR are recently reported to play an important role in the development of gastropod imposex, by showing the cloning of an RXR homolog from a marine gastropod, binding of organotins to that receptor, and imposex induction by injection of 9cRA (Nishikawa et al., 2004; Castro et al., 2007). These findings indicated that RXR activation is also a critical event for endocrine disruption of organotins in gastropods. However, it is possible that organotin compounds affect target molecules other than PPAR $\gamma$ and RXR. For instance, organotin compounds have been shown to enhance histone acetyltransferase activity (Osada et al., 2005). Further studies are needed to clarify the precise action mechanism of the toxicity of organotin compounds in mammals in vitro and in vivo, because they appear intricate.

\section{ACKNOWLEDGMENTS}

We thank Dr. Keiichi Tanaka (Faculty of Pharmacy, Osaka Ohtani University), Dr. Jun-ichi Nishikawa (School of Pharmacy and Pharmaceutical Sciences, Mukogawa Women's University) and our laboratory staff for their helpful discussions. This work was supported in part by: Grants-in-Aid for Scientific Research from the Ministry of Education, Science, Sports and Culture of Japan; the Industrial Technology Research Grant Program in 2001 from the New Energy and Industrial Technology Development Organization (NEDO) of Japan; Health and Labor Sciences Research Grants (Research on Advanced Medical Technology) from the Ministry of Health, Labor and Welfare of Japan; LRI (The Long-Range Research Initiative, Japan).

\section{REFERENCES}

Adeeko, A., Li, D., Forsyth, D.S., Casey, V., Cooke, G.M., Barthelemy, J., Cyr, D.G., Trasler, J.M., Robaire, B. and Hales, B.F. (2003): Effects of in utero tributyltin chloride exposure in the rat on pregnancy outcome. Toxicol. Sci., 74, 407-415.

Aranda, A. and Pascual, A. (2001): Nuclear hormone receptors and gene expression. Physiol. Rev., 81, 1269-1304.

Bamberger, A.M., Ezzat, S., Cao, B., Wong, M., Parker, K.L., Schulte, H.M. and Asa, S.L. (1996): Expression of steroidogenic factor-1 (SF-1) mRNA and protein in the human placenta. Mol. Hum. Reprod., 2, 457-461.

Bardot, O., Aldridge, T.C., Latruffe, N. and Green, S. (1993): PPAR- 
Endocrine disruption of organotins via nuclear receptor signaling

RXR heterodimer activates a peroxisome proliferator response element upstream of the bifunctional enzyme gene. Biochem. Biophys. Res. Commun., 192, 37-45.

Bettin, C., Oehlmann, J. and Stroben, E. (1996): TBT-induced imposex in marine neogastropods is mediated by an increasing androgen level. Helgol. Meeresunters., 50, 299-317.

Boyer, I.J. (1989): Toxicity of dibutyltin, tributyltin and other organotin compounds to humans and to experimental animals. Toxicology, 55, 253-298.

Bulun, S.E., Sebastian, S., Takayama, K., Suzuki, T., Sasano, H. and Shozu, M. (2003): The human CYP19 (aromatase P450) gene: update on physiologic roles and genomic organization of promoters. J. Steroid Biochem. Mol. Biol., 86, 219-224.

Castro, L.F., Lima, D., Machado, A., Melo, C., Hiromori, Y., Nishikawa, J., Nakanishi, T., Reis-Henriques, M.A. and Santos, M.M. (2007): Imposex induction is mediated through the Retinoid X Receptor signalling pathway in the neogastropod Nucella lapillus. Aquat. Toxicol., 85, 57-66.

Chambon, P. (1996): A decade of molecular biology of retinoic acid receptors. FASEB J., 10, 940-954.

Chuang, K.H., Lee, Y.F., Lin, W.J., Chu, C.Y., Altuwaijri, S., Wan, Y.J. and Chang, C. (2005): 9-cis-retinoic acid inhibits androgen receptor activity through activation of retinoid X receptor. Mol. Endocrinol., 19, 1200-1212.

Cooke, G.M. (2002): Effect of organotins on human aromatase activity in vitro. Toxicol. Lett., 126, 121-130.

Doering, D.D., Steckelbroeck, S., Doering, T. and Klingmüller, D. (2002): Effects of butyltins on human $5 \alpha$-reductase type 1 and type 2 activity. Steroids, 67, 859-867.

Duvic, M., Hymes, K., Heald, P., Breneman, D., Martin, A.G., Myskowski, P., Crowley, C. and Yocum, R.C. (2001): Bexarotene is effective and safe for treatment of refractory advancedstage cutaneous T-cell lymphoma: multinational phase II-III trial results. J. Clin. Oncol., 19, 2456-2471.

Escriva, H., Safi, R., Hänni, C., Langlois, M.C., Saumitou-Laprade, P., Stehelin, D., Capron, A., Pierce, R. and Laudet, V. (1997): Ligand binding was acquired during evolution of nuclear receptors. Proc. Natl. Acad. Sci. USA, 94, 6803-6808.

Escriva, H., Delaunay, F. and Laudet, V. (2000): Ligand binding and nuclear receptor evolution. Bioessays, 22, 717-727.

Fan, W., Yanase, T., Morinaga, H., Mu, Y.M., Nomura, M., Okabe, T., Goto, K., Harada, N. and Nawata, H. (2005): Activation of peroxisome proliferator-activated receptor- $\gamma$ and retinoid $\mathrm{X}$ receptor inhibits aromatase transcription via nuclear factor- $\mathrm{\kappa B}$. Endocrinology, 146, 85-92.

Fent, K. (1996): Ecotoxicology of organotin compounds. Crit. Rev. Toxicol., 26, 3-117.

Forman, B.M., Umesono, K., Chen, J. and Evans, R.M. (1995): Unique response pathways are established by allosteric interactions among nuclear hormone receptors. Cell, 81, 541-550.

Germain, P., Iyer, J., Zechel, C. and Gronemeyer, H. (2002): Coregulator recruitment and the mechanism of retinoic acid receptor synergy. Nature, $\mathbf{4 1 5}, 187-192$.

Giguere, V. (1994): Retinoic acid receptors and cellular retinoid binding proteins: complex interplay in retinoid signaling. Endocr. Rev., 15, 61-79.

Grün, F., Watanabe, H., Zamanian, Z., Maeda, L., Arima, K., Cubacha, R., Gardiner, D.M., Kanno, J., Iguchi, T. and Blumberg, B. (2006): Endocrine-disrupting organotin compounds are potent inducers of adipogenesis in vertebrates. Mol. Endocrinol., 20, 2141-2155.

Heidrich, D.D., Steckelbroeck, S. and Klingmuller, D. (2001):
Inhibition of human cytochrome $\mathrm{P} 450$ aromatase activity by butyltins. Steroids, 66, 763-769.

Horiguchi, T., Shiraishi, H., Shimizu, M. and Morita, M. (1997): Effects of triphenyltin chloride and five other organotin compounds on the development of imposex in the rock shell, Thais clavigera. Environ. Pollut., 95, 85-91.

Issemann, I., Prince, R.A., Tugwood, J.D. and Green, S. (1993): The peroxisome proliferator-activated receptor:retinoid $\mathrm{X}$ receptor heterodimer is activated by fatty acids and fibrate hypolipidaemic drugs. J. Mol. Endocrinol., 11, 37-47.

Kanayama, T., Mamiya, S., Nishihara, T. and Nishikawa, J. (2003): Basis of a high-throughput method for nuclear receptor ligands. J. Biochem. (Tokyo), 133, 791-797.

Kanayama, T., Kobayashi, N., Mamiya, S., Nakanishi, T. and Nishikawa, J. (2005): Organotin compounds promote adipocyte differentiation as agonists of the peroxisome proliferator-activated receptor $\gamma /$ retinoid X receptor pathway. Mol. Pharmacol., 67, 766-774.

Kannan, K., Senthilkumar, K. and Giesy, J.P. (1999): Occurrence of butyltin compounds in human blood. Environ. Sci. Technol., 33, 1776-1779.

Kliewer, S.A., Umesono, K., Noonan, D.J., Heyman, R.A. and Evans, R.M. (1992): Convergence of 9-cis retinoic acid and peroxisome proliferator signalling pathways through heterodimer formation of their receptors. Nature, 358, 771-774.

Laffitte, B.A., Kast, H.R., Nguyen, C.M., Zavacki, A.M., Moore, D.D. and Edwards, P.A. (2000): Identification of the DNA binding specificity and potential target genes for the farnesoid X-activated receptor. J. Biol. Chem., 275, 10638-10647.

Lee, R.F. (1985): Metabolism of tributyltin oxide by crabs, oysters and fish. Mar. Environ. Res., 17, 145-148.

Lehmann, J.M., Moore, L.B., Smith-Oliver, T.A., Wilkison, W.O., Willson, T.M. and Kliewer, S.A. (1995): An antidiabetic thiazolidinedione is a high affinity ligand for peroxisome proliferatoractivated receptor $\gamma$ (PPAR $\gamma$ ). J. Biol. Chem., 270, 12953-12956.

Liu, S., Ogilvie, K.M., Klausing, K., Lawson, M.A., Jolley, D., Li, D., Bilakovics, J., Pascual, B., Hein, N., Urcan, M. and Leibowitz, M.D. (2002): Mechanism of selective retinoid X receptor agonist-induced hypothyroidism in the rat. Endocrinology, 143, 2880-2885.

Lo, S., Allera, A., Albers, P., Heimbrecht, J., Jantzen, E., Klingmuller, D. and Steckelbroeck, S. (2003): Dithioerythritol (DTE) prevents inhibitory effects of triphenyltin (TPT) on the key enzymes of the human sex steroid hormone metabolism. J. Steroid Biochem. Mol. Biol., 84, 569-576.

Matthiessen, P. and Gibbs, P.E. (1998): Critical appraisal of the evidence for tributyltin-mediated endocrine disruption in mollusks. Environ. Toxicol. Chem., 17, 37-43.

McVey, M.J. and Cooke, G.M. (2003): Inhibition of rat testis microsomal $3 \beta$-hydroxysteroid dehydrogenase activity by tributyltin. J. Steroid Biochem. Mol. Biol., 86, 99-105.

Michael, M.D., Kilgore, M.W., Morohashi, K. and Simpson, E.R. (1995): Ad4BP/SF-1 regulates cyclic AMP-induced transcription from the proximal promoter (PII) of the human aromatase P450 (CYP19) gene in the ovary. J. Biol. Chem., 270, 13561-13566.

Mu, Y.M., Yanase, T., Nishi, Y., Waseda, N., Oda, T., Tanaka, A., Takayanagi, R. and Nawata, H. (2000): Insulin sensitizer, troglitazone, directly inhibits aromatase activity in human ovarian granulosa cells. Biochem. Biophys. Res. Commun., 271, 710713.

Mu, Y.M., Yanase, T., Nishi, Y., Takayanagi, R., Goto, K. and Nawata, H. (2001): Combined treatment with specific ligands 
T. Nakanishi

for PPAR $\gamma:$ RXR nuclear receptor system markedly inhibits the expression of cytochrome P450arom in human granulosa cancer cells. Mol. Cell. Endocrinol., 181, 239-248.

Mukherjee, R., Davies, P.J., Crombie, D.L., Bischoff, E.D., Cesario, R.M., Jow, L., Hamann, L.G., Boehm, M.F., Mondon, C.E., Nadzan, A.M., Paterniti, J.R., Jr. and Heyman, R.A. (1997): Sensitization of diabetic and obese mice to insulin by retinoid $X$ receptor agonists. Nature, 386, 407-410.

Nakanishi, T., Kohroki, J., Suzuki, S., Ishizaki, J., Hiromori, Y., Takasuga, S., Itoh, N., Watanabe, Y., Utoguchi, N. and Tanaka, K. (2002): Trialkyltin compounds enhance human CG secretion and aromatase activity in human placental choriocarcinoma cells. J. Clin. Endocrinol. Metab., 87, 2830-2837.

Nakanishi, T., Nishikawa, J., Hiromori, Y., Yokoyama, H., Koyanagi, M., Takasuga, S., Ishizaki, J., Watanabe, M., Isa, S., Utoguchi, N., Itoh, N., Kohno, Y., Nishihara, T. and Tanaka, K. (2005): Trialkyltin compounds bind retinoid X receptor to alter human placental endocrine functions. Mol. Endocrinol., 19, 2502-2516.

Nakanishi, T., Hiromori, Y., Yokoyama, H., Koyanagi, M., Itoh, N., Nishikawa, J. and Tanaka, K. (2006): Organotin compounds enhance $17 \beta$-hydroxysteroid dehydrogenase type I activity in human choriocarcinoma JAr cells: potential promotion of $17 \beta-$ estradiol biosynthesis in human placenta. Biochem. Pharmacol., 71, 1349-1357.

Nishikawa, J., Mamiya, S., Kanayama, T., Nishikawa, T., Shiraishi, F. and Horiguchi, T. (2004): Involvement of the retinoid $\mathrm{X}$ receptor in the development of imposex caused by organotins in gastropods. Environ. Sci. Technol., 38, 6271-6276.

Ohno, S., Nakajima, Y. and Nakajin, S. (2005): Triphenyltin and Tributyltin inhibit pig testicular 17ß-hydroxysteroid dehydrogenase activity and suppress testicular testosterone biosynthesis. Steroids, 70, 645-651.

Osada, S., Nishikawa, J., Nakanishi, T., Tanaka, K. and Nishihara, T. (2005): Some organotin compounds enhance histone acetyltransferase activity. Toxicol. Lett., 155, 329-335.

Rantakokko, P., Kuningas, T., Saastamoinen, K. and Vartiainen, T. (2006): Dietary intake of organotin compounds in Finland: a market-basket study. Food Addit. Contam., 23, 749-756.

Saitoh, M., Yanase, T., Morinaga, H., Tanabe, M., Mu, Y.M., Nishi, Y., Nomura, M., Okabe, T., Goto, K., Takayanagi, R. and Nawata, H. (2001): Tributyltin or triphenyltin inhibits aromatase activity in the human granulosa-like tumor cell line KGN. Biochem. Biophys. Res. Commun., 289, 198-204.

Schulman, I.G., Shao, G. and Heyman, R.A. (1998): Transactivation by retinoid $\mathrm{X}$ receptor-peroxisome proliferator-activated receptor $\gamma($ PPAR $\gamma)$ heterodimers: intermolecular synergy requires only the PPAR $\gamma$ hormone-dependent activation function. Mol. Cell. Biol., 18, 3483-3494.

Sebastian, S. and Bulun, S.E. (2001): A highly complex organization of the regulatory region of the human CYP19 (aromatase) gene revealed by the Human Genome Project. J. Clin. Endocrinol. Metab., 86, 4600-4602.

Simpson, E.R., Mahendroo, M.S., Means, G.D., Kilgore, M.W., Hinshelwood, M.M., Graham-Lorence, S., Amarneh, B., Ito, Y., Fisher, C.R., Michael, M.D., Mendelson, C.R. and Bulun, S.E. (1994): Aromatase cytochrome P450, the enzyme responsible for estrogen biosynthesis. Endocr. Rev., 15, 342-355.

Simpson, E.R., Michael, M.D., Agarwal, V.R., Hinshelwood, M.M., Bulun, S.E. and Zhao, Y. (1997): Cytochromes P450 11: expression of the CYP19 (aromatase) gene: an unusual case of alternative promoter usage. FASEB J., 11, 29-36.

Sun, T., Zhao, Y., Mangelsdorf, D.J. and Simpson, E.R. (1998): Characterization of a region upstream of exon I.1 of the human CYP19 (aromatase) gene that mediates regulation by retinoids in human choriocarcinoma cells. Endocrinology, 139, 1684-1691.

Takahashi, S., Mukai, H., Tanabe, S., Sakayama, K., Miyazaki, T. and Masuno, H. (1999): Butyltin residues in livers of humans and wild terrestrial mammals and in plastic products. Environ. Pollut., 106, 213-218.

Thompson, P.D., Jurutka, P.W., Haussler, C.A., Whitfield, G.K. and Haussler, M.R. (1998): Heterodimeric DNA binding by the vitamin $D$ receptor and retinoid $X$ receptors is enhanced by 1,25 dihydroxyvitamin D3 and inhibited by 9 -cis-retinoic acid. Evidence for allosteric receptor interactions. J. Biol. Chem., 273, 8483-8491.

Tontonoz, P., Hu, E. and Spiegelman, B.M. (1994): Stimulation of adipogenesis in fibroblasts by PPAR $\gamma 2$, a lipid-activated transcription factor. Cell, 79, 1147-1156.

Tsuda, T., Inoue, T., Kojima, M. and Aoki, S. (1995): Daily intakes of tributyltin and triphenyltin compounds from meals. J. AOAC Int., 78, 941-943.

Watanabe, H., Adachi, R., Hirayama, A., Kasahara, T. and Suzuki, K. (2003): Triphenyltin enhances the neutrophilic differentiation of promyelocytic HL-60 cells. Biochem. Biophys. Res. Commun., 306, 26-31.

Westin, S., Kurokawa, R., Nolte, R.T., Wisely, G.B., McInerney, E.M., Rose, D.W., Milburn, M.V., Rosenfeld, M.G. and Glass, C.K. (1998): Interactions controlling the assembly of nuclearreceptor heterodimers and co-activators. Nature, 395, 199-202.

Yamabe, Y., Hoshino, A., Imura, N., Suzuki, T. and Himeno, S. (2000): Enhancement of androgen-dependent transcription and cell proliferation by tributyltin and triphenyltin in human prostate cancer cells. Toxicol. Appl. Pharmacol., 169, 177-184. 